\title{
Influence of Lamellar Thickness on Strength and Stiffness of Glued Laminated Timber Beams of Pinus oocarpa
}

\author{
Felipe Hideyoshi Icimoto ${ }^{1}$, Carlito Calil Neto ${ }^{2}$, Fabiane S. Ferro ${ }^{1}$, Laurenn Borges de Macedo ${ }^{1}$, \\ André Luis Christoforo ${ }^{3, *}$, Francisco Antonio Rocco Lahr ${ }^{4}$, Carlito Calil Júnior ${ }^{4}$ \\ ${ }^{1}$ Department of Materials (SMM), São Paulo University (EESC/USP), São Carlos, Brazil \\ ${ }^{2}$ Wood and Timber Structures Laboratory (LaMEM), São Carlos Engineering School, São Paulo University - USP, São Carlos, Brazil \\ ${ }^{3}$ Centre for Innovation and Technology in Composites - CITeC, Department of Civil Engineering (DECiv), Federal University of São \\ Carlos, São Carlos, Brazil \\ ${ }^{4}$ Department of Structural Engineering (SET), São Paulo University (EESC/USP), São Carlos, Brazil
}

\begin{abstract}
Glued laminated timber is a structural engineered product that requires precision and strict quality control in its manufacture. For ensure that produced elements properties are in compliance with regulatory requirements, final product must be tested under laboratory conditions. Determining factors in final glulam pieces cost are the type and the quantity of adhesive used in structural elements manufacture. This study aimed to investigate, aided by three point static bending tests and variance analysis (ANOVA), influence of glue lines $(3,5,7)$ and lamellae $(4,6,8)$ on strength (MOR) and stiffness (MOE) properties of glulam beams manufactured with Pinus oocarpa (CCA treated) and bonded with Phenol Resorcinol resin (Cascophen RS-216-M). These beams presented nominal dimensions 90mm wide; $100 \mathrm{~mm}$ height; and 1350mm length. For $100 \mathrm{~mm}$ fixed height, three beams configurations were tested (a) with four lamellae of $25 \mathrm{~mm}$ (3 glue lines); with 6 lamellae of 16,7 mm (5 glue lines) and 8 lamellae of $12.5 \mathrm{~mm}$ each (7glue lines), being fabricated 6 beams for experimental condition. In addition to investigating influence of glue lines and lamellae number, possibility of estimating MOE and MOR based on apparent density was also evaluated. ANOVA results showed no significance about glue lines number (or lamellae thickness) in strength and stiffness values, implying, for economic reasons, be configuration with four $25 \mathrm{~mm}$ lamellae the best among tested beams. From regressions, apparent density was only significant in MOE estimating $\left(\mathrm{R}^{2}=46.90 \%\right)$, indicating not be possible to estimate the stiffness and strength values of the glued laminated timber evaluated by the apparent density.
\end{abstract}

Keywords Glued laminated timber, Lamellae thickness, Lamellae number, Mechanical performance, Pinus oocarpa

\section{Introduction}

Glued laminated timber (Glulam) is a structural product used for many years in countries with extensive experience in build timber structures, such as USA, Canada, Germany and Switzerland [1].

As an engineered product, its production process requires an industry with quality control on manufacturing steps by trained manpower and raw material with compatible performance to requirements of products [2-6].

To ensure that the Glulam element properties are in compliance with normative requirements and material strength is specified according to current codes, the final product must be tested under laboratory conditions [7].

Nowadays, Glulam production in Brazil is still not so wide, being necessary greater disclosure of this technology, by

* Corresponding author:

christoforoal@yahoo.com.br (André Luis Christoforo)

Published online at http://journal.sapub.org/ijme

Copyright (C) 2016 Scientific \& Academic Publishing. All Rights Reserved uniting efforts of researchers, engineers, architects and industries. This is, therefore, a possible way to Glulam achieve visibility, competitiveness and economic viability in relation to other structural materials $[1,8-10]$.

In order to provide competitiveness to Glulam in opposite to other building materials, such as reinforced concrete and steel, beyond of disclosure aiming to increase demand, it is also necessary to develop researches aiming lowering final product cost, that can occur with improvement of manufacturing processes as well as with raw materials economy $[4,6]$.

Raw materials used to produce Glulam are wood and adhesive. Wood is the main element and adhesive is responsible to join together timber pieces for adequate shaping the final products. Cost of adhesive, in several cases, can be higher than wood. Therefore, usually it is preferable to use more wood and less adhesive. Consequently, more glue lines in structural elements will signify the higher products cost [8].

Considering the possibility of economy and more rational use of glued laminated timber, this study aimed to investigate 
influence of glue lines number (or number of lamellae) on strength (MOR) and stiffness (MOE), in static bending, of glulam beams produced with CCA (Chromated Copper Arsenate) treated Pinus oocarpa.

Besides, this research also aimed to evaluate the possibility of estimating these properties based on apparent density, once it's a wood characteristic of easy determination.

\section{Material and Methods}

Wood species used for specimen fabrication was Pinus oocarpa, air-dried (12\% moisture content) and CCA treated.

Modulus of elasticity (MOE) and modulus of rupture (MOR) of Glulam beams (nominal dimensions $90 \mathrm{~mm}$ wide; $100 \mathrm{~mm}$ height; and $1350 \mathrm{~mm}$ length) were obtained using three point static bending tests (Figure 1), the same structural model proposed by Brazilian normative document [11] for small clear specimens.

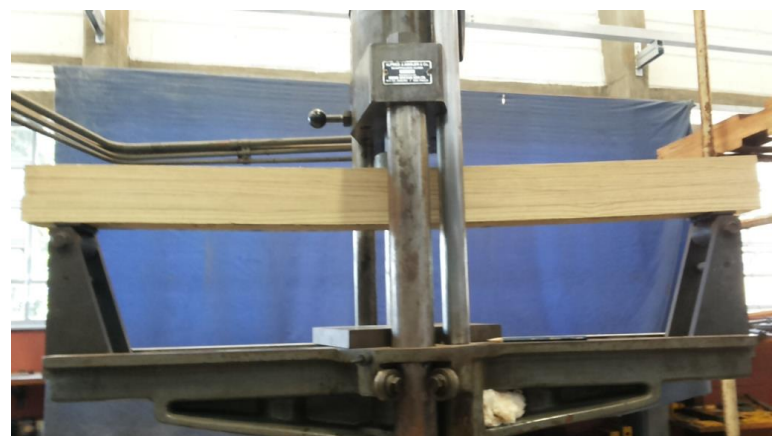

Figure 1. Three point static bending test

Six beams, $100 \mathrm{~mm}$ high, with four $25 \mathrm{~mm}$ thickness lamellae (three glue lines); more six beams with six lamellae of $16,70 \mathrm{~mm}$ in height each (five glue lines) and another six beams with 8 lamellae of $12.50 \mathrm{~mm}$ in height each (seven glue lines) were produced. This resulted in three experimental conditions, a total of 54 determinations.

Figure 2 illustrates the experimental conditions investigated in this study.

Adhesive used in specimens manufacture was Cascophen RS-216-M, a well-known resin used by Glulam companies in Brazil and around world [1].

Cascophen is a synthetic resin based on resorcinol, especially recommended for bonding that resists to cold or boiling water, to organic solvents, to mold and mildew, to dry heat or wet etc. It is a structural resin, suitable for bonding wood by cold cure process under pressure. Among its applications, stand out boats, ladders, water tanks, propellers, Glulam beams among others, where gluing will be temporarily or permanently exposed to weathering [2-5].

After separation by thickness, lamellae were visually rated according American Standard ASTM D245 [13]. Following, the lamellae were glued together (glue line with a weight of $350 \mathrm{~g} / \mathrm{m}^{2}$ ) under $1 \mathrm{MPa}$ pressure.

Figures 3 and 4 , in sequence, display the gluing procedures and the pressing of Glulam beams, respectively.

For investigating influence of glue line number $(3,5,7)$ or lamellae thickness in obtaining modulus of elasticity (MOE) and modulus of rupture (MOR), in static bending, variance analysis (ANOVA) was used, at 5\% significance $(\alpha)$, considering means equivalence between treatments as null hypothesis $\left(\mathrm{H}_{0}\right)$ and non-equivalence as alternative hypothesis $\left(\mathrm{H}_{1}\right)$. P-value below significance level implies reject $\mathrm{H}_{0}$, accepting it otherwise. Anderson-Darling test was used to evaluate normal distribution, by answer, and Bartlett's test to evaluate treatment variances homogeneity, both measured at 5\% significance level. P-value greater than 0.05 implies normal distribution and variance homogeneity among treatments by answer, validating model ANOVA.

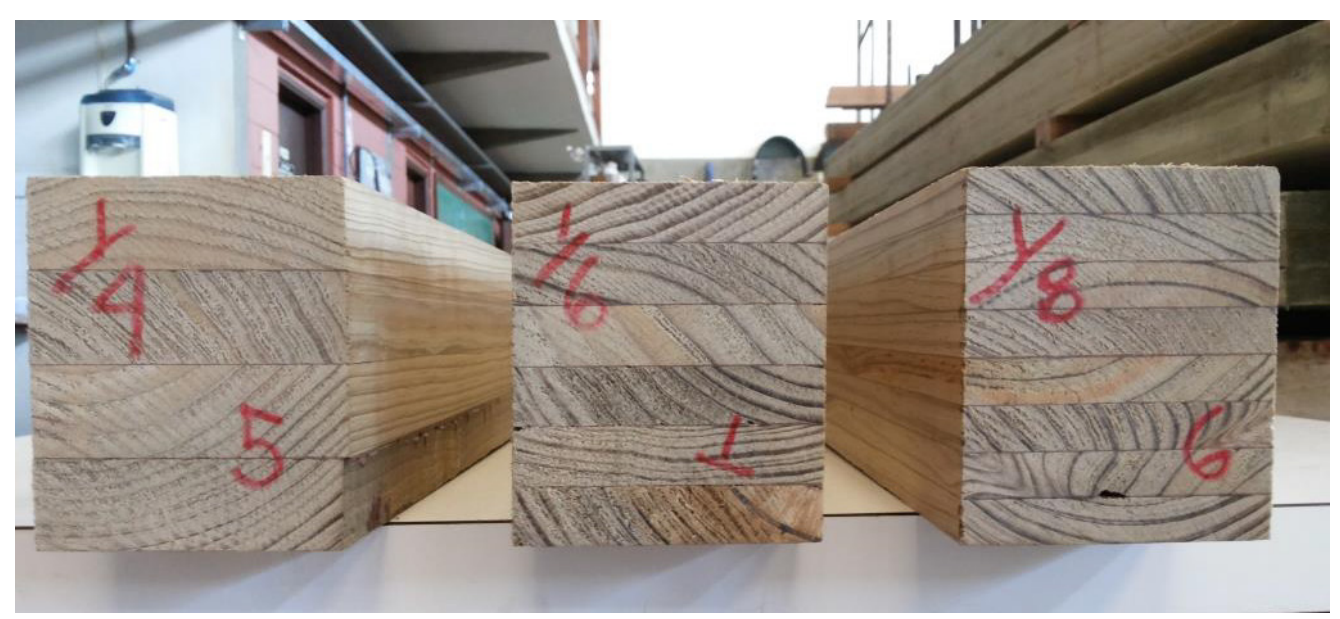

(a)

(b)

(c)

Figure 2. Experimental conditions to Pinus oocarpa glulam beams - 4 lamellae (a), 6 lamellae (b) and 8 lamellae (c) 


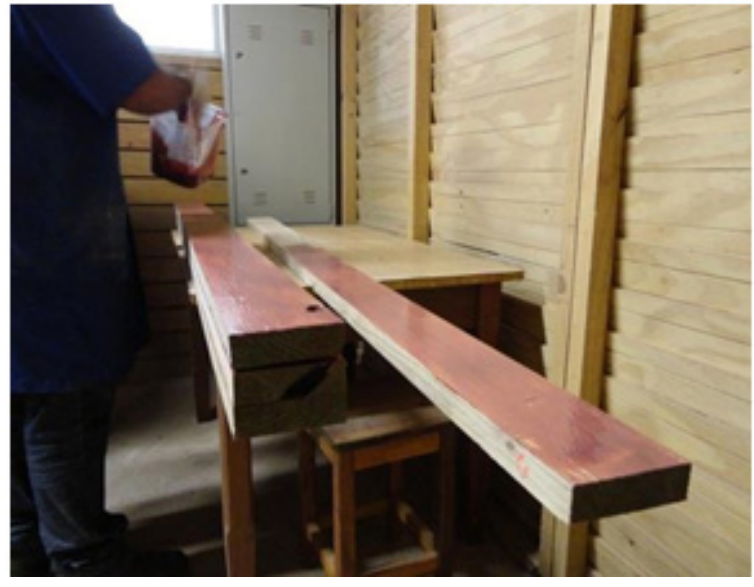

(a)

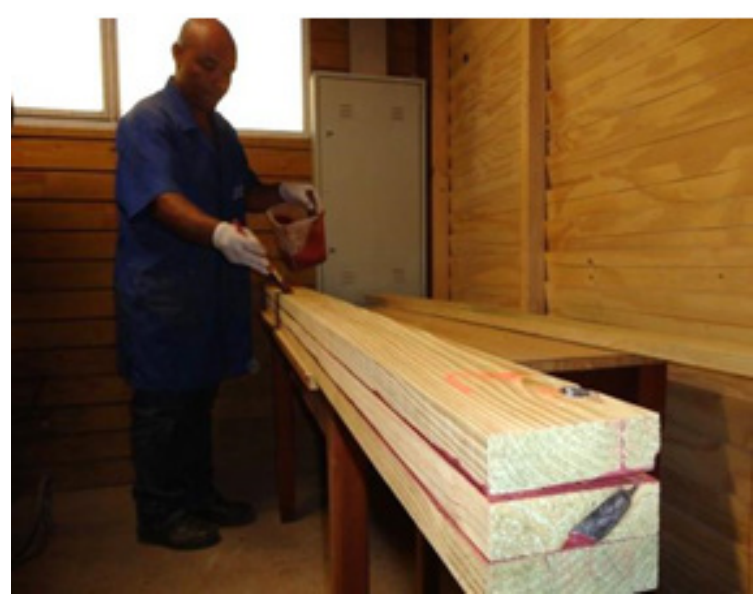

(b)

Figure 3. Gluing CCA treated glulam beams

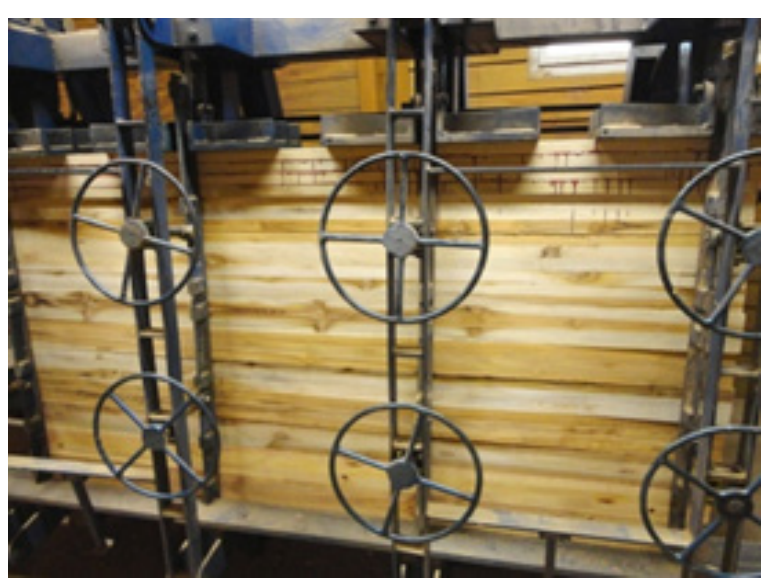

Figure 4. CCA treated Pinus oocarpa glulam beams

For being an property of easy experimental obtaining, apparent density ( $\rho 12)$ was used to estimate modulus of elasticity and modulus of rupture on static bending of the glulam beams fabricated. To this end, linear regression models based on variance analysis were used, also at $5 \%$ significance level. By hypothesis formulation, P-value greater than significance level implies considering that the tested model is not significant, and significant otherwise. The adjusted determination coefficient was used to evaluate tested settings quality.

\section{Results and Discussion}

Table 1 shows mean $(\bar{x})$, variation coefficients $(\mathrm{Cv})$ and minors (Min) and higher (Max) values of modulus of elasticity (MOE) and modulus of rupture (MOR) on static bending as well as Glulam beams apparent density values.

Table 1. Investigated properties results of Pinus oocarpa glulam beams

\begin{tabular}{|c|c|c|c|}
\hline \multirow{2}{*}{ Statistics } & \multicolumn{3}{|c|}{$25 \mathrm{~mm}$ thickness lamellae (4 lamellae - 3 glue lines) } \\
\hline & MOE (MPa) & MOR (MPa) & $\rho_{12}\left(\mathrm{~kg} / \mathrm{m}^{3}\right)$ \\
\hline $\bar{x}$ & 12762 & 94.85 & 0.63 \\
\hline$C v(\%)$ & 10 & 4 & 5 \\
\hline Min & 11224 & 90.64 & 0.58 \\
\hline $\operatorname{Max}$ & 15031 & 100.66 & 0.68 \\
\hline \multirow{2}{*}{ Statistics } & \multicolumn{3}{|c|}{$16,7 \mathrm{~mm}$ thickness lamellae (6 lamellae - 5 glue lines) } \\
\hline & MOE (MPa) & MOR (MPa) & $\rho_{12}\left(\mathrm{~kg} / \mathrm{m}^{3}\right)$ \\
\hline $\bar{x}$ & 13028 & 96,63 & 0.66 \\
\hline$C v(\%)$ & 11 & 12 & 5 \\
\hline Min & 10732 & 83.13 & 0.61 \\
\hline $\operatorname{Max}$ & 14719 & 112.37 & 0.70 \\
\hline \multirow{2}{*}{ Statistics } & \multicolumn{3}{|c|}{$12.5 \mathrm{~mm}$ thickness lamellae (8 lamellae - 7 glue lines) } \\
\hline & MOE (MPa) & MOR (MPa) & $\rho_{12}\left(\mathrm{~kg} / \mathrm{m}^{3}\right)$ \\
\hline $\bar{x}$ & 12813 & 90.12 & 0.64 \\
\hline$C v(\%)$ & 4 & 10 & 4 \\
\hline Min & 12047 & 77.07 & 0.60 \\
\hline $\operatorname{Max}$ & 13400 & 96.96 & 0.67 \\
\hline
\end{tabular}

It is possible to note that physical and mechanical properties values of glulam beams vary little from an experiential condition to another.

Figures 5 and 6 illustrate normality and variance homogeneity test results of mechanical properties, respectively.

By P-values found in normality tests (Figure 1) and variance homogeneity (Table 2) are both greater than significance level (0.05), it may be concluded that distributions by answer are normal and variances between groups are homogeneous, thus validating ANOVA model. Tables 2 and 3 show ANOVA results of glue lines number influence (NLC) on MOE and MOR values. DF means freedom degrees, SS squares sum, MS square mean, F is Fisher statistic and P-value is the probability $\mathrm{P}$.

From Tables 2 and 3, it can be noted that P-values were both greater than 0.05 , providing evidence that lamellae number (or glue lines number) evaluated were not significant in determining of strength and stiffness values of Glulam beams. This implies, on economic issues, that configuration with four lamellae or three glue lines is the best solution among experimental conditions investigated. 


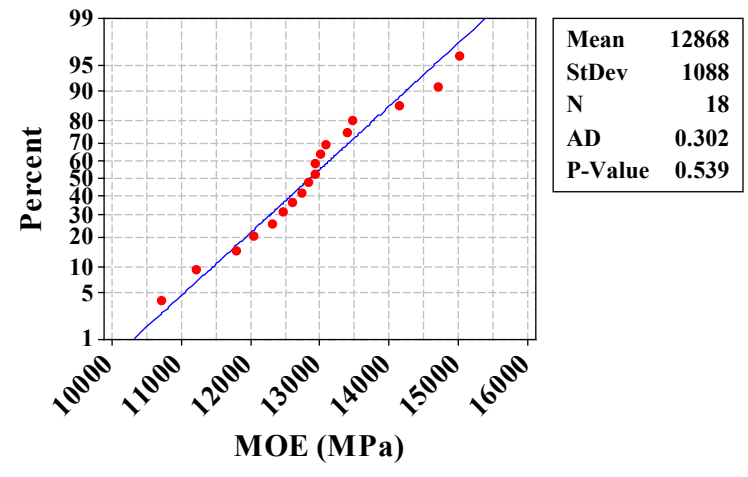

(a)

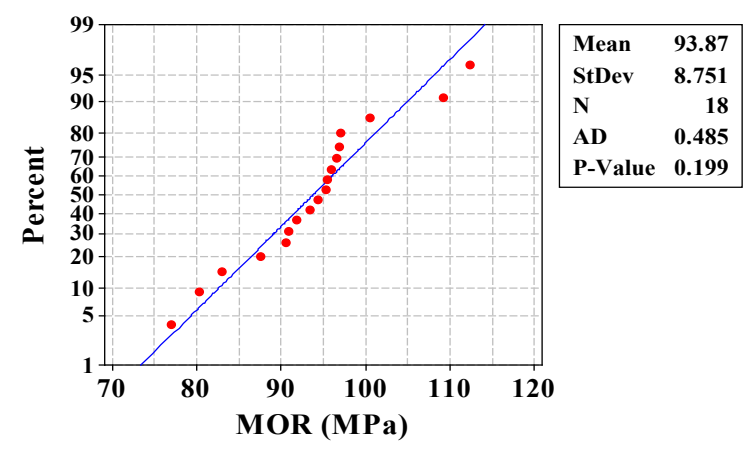

(b)

Figure 5. Normality tests: $\mathrm{MOE}$ (a) and MOR (b)

Table 2. ANOVA results for MOE

\begin{tabular}{cccccc}
\hline Source & DF & SS & MS & F & P-value \\
\hline NLC & 2 & 237563 & 118782 & 0.09 & 0.915 \\
Error & 15 & 19871522 & 1324768 & & \\
Total & 17 & 20109086 & & & \\
\hline
\end{tabular}

Table 3. ANOVA results for MOR.

\begin{tabular}{cccccc}
\hline Source & DF & SS & MS & F & P-value \\
\hline NLC & 2 & 135.9 & 67.9 & 0.87 & 0.437 \\
Error & 15 & 1166.0 & 77.7 & & \\
Total & 17 & 1301.8 & & & \\
\hline
\end{tabular}

Equations 1 and 2 show results of regression models and Figure 7 the adjustments obtained using these equations.

$$
\begin{array}{r}
\operatorname{MOE}(M P a)=-3869+26046 \cdot \rho_{12}\left(\mathrm{~kg} / \mathrm{cm}^{3}\right) \\
\mathrm{R}^{2}(\mathrm{adj})=46.5 \% ; \quad \text { P-value }=0.001 \\
\operatorname{MOR}(M P a)=45,02+76,02 \cdot \rho_{12}\left(\mathrm{~kg} / \mathrm{cm}^{3}\right) \\
\mathrm{R} 2(\operatorname{adj})=0.70 \% ; \quad \text { P-value }=0.306
\end{array}
$$

By ANOVA of regression models, density apparent was significant only on MOE estimation, however, with adjusted determination coefficient less than $50 \%$. This means that only $50 \%$ of MOE values are explained by apparent density. So, this did not appear as good estimates of mechanical properties.

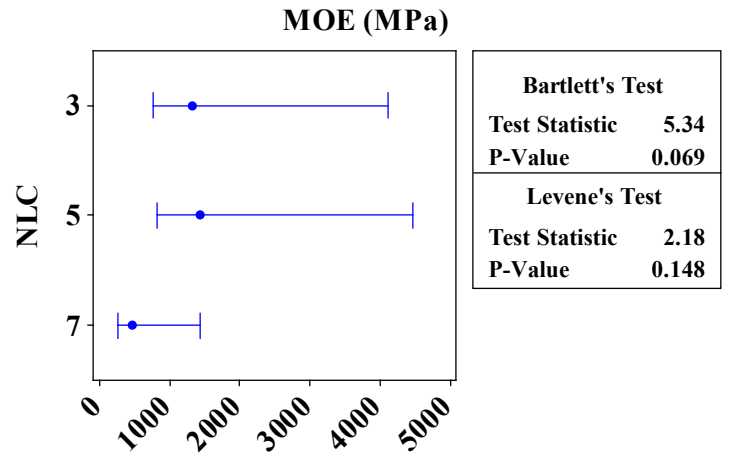

(a)

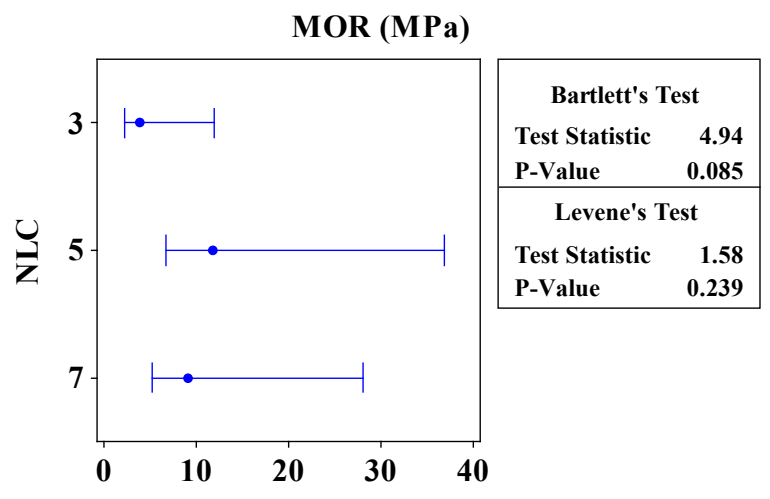

(b)

Figure 6. Variance homogeneity test: MOE (a) and MOR (b)

\section{Conclusions}

Results obtained in this study can led to conclude that variation of lamellae thickness $(12,5 \mathrm{~mm}, 16,70 \mathrm{~mm}, 25 \mathrm{~mm})$ or glue lines number $(3,5,7)$ did not influence significantly on strength and stiffness in bending, conducting to equivalent results.

Thus, searching of economy associated with Glulam beams manufacturing, the best configuration investigated consists in using $25 \mathrm{~mm}$ thickness lamellae, thereby decreasing adhesive amount, which provides:

- reduction of costs involved in gluing;

- handling and processing a smaller number of lamellae for final product manufacture;

- reduction in the assembly time of beams by the industry.

The visual classification of pieces enabled producing Glulam beams free from defects, which resulted in small variability found for values of mechanical and physical properties investigated, wherein the largest value of variation coefficient did not exceed $12 \%$.

Visual and mechanical classification in lamellae and tests on Glulam elements in structural size are highly recommended, because volume factor is important in using glulam. 


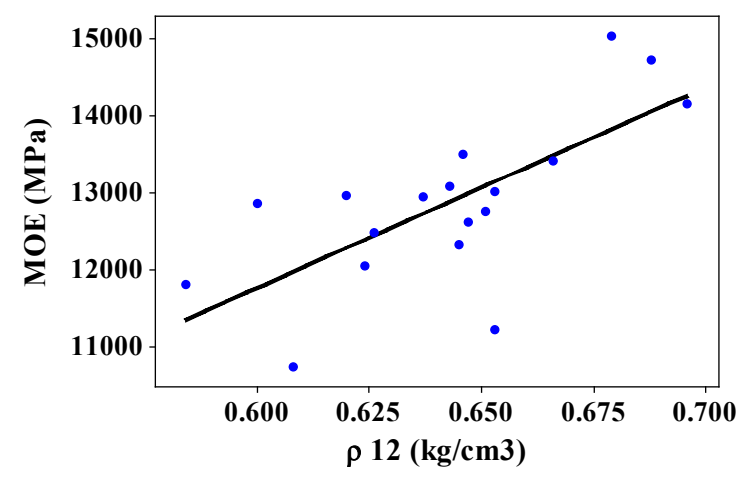

(a)

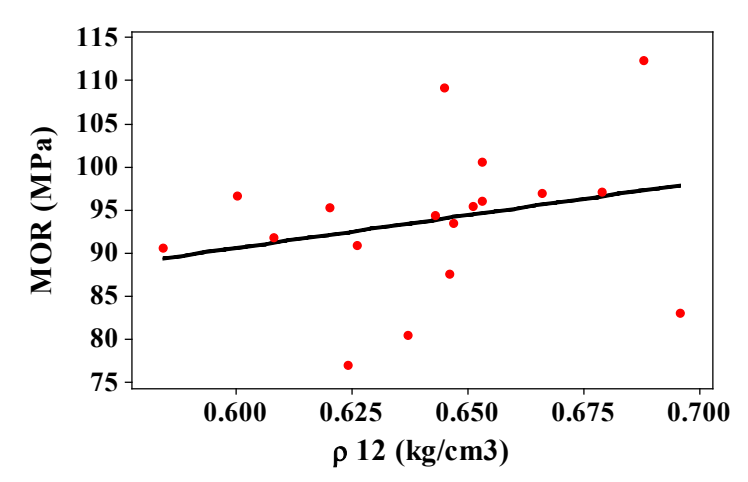

(b)

Figure 7. Adjustments by linear regression models: MOE (a) and MOR (b)

From estimation of mechanical properties as a function of apparent density, only to modulus of elasticity was found meaningful model. However, even though significant linear model to estimate MOE, the determination coefficient adjusted was less than $50 \%$, evidencing that density did not led as good estimate in determining strength and stiffness values.

\section{REFERENCES}

[1] Icimoto, F. H. Glulam railway sleepers made with Pinus oocarpa wood specie. Dissertation (Master in Science and Materials Engineering). School of Engineering of São Carlos, University of São Paulo, São Carlos, 125 p., 2013.

[2] American Institute of Timber Construction, AITC, 200-2004 Manufacturing Quality Control Systems Manual, Centennial,
Colorado, 118p., 2004.

[3] Rocco Lahr, F. A.; Almeida, D. H.; Cavalheiro, R. S.; Macedo, L. B.; Calil Neto, C.; Christoforo, A. L.; Calil Junior, C. Evaluation of Quality in the Adhesion of Glued Laminated Timber (Glulam) of Paricá and Lyptus Wood Species. International Journal of Materials Engineering, v. 4, p. 114-118, 2014.

[4] Rocco, F. A. L.; Christoforo, A. L.; Campos, C. I.; Morales, E. A. M.; Barbosa, J. C.; Panzera, T. H. Evaluation of the Moisture Content in Stiffness Properties of Structural Glulam Beams. Advanced Materials Research (Online), v. 1088, p. 676-679, 2015.

[5] Calil Neto, C.; Christoforo, A. L.; Rocco, F. A. L.; Calil Junior, C. Analysis of Specie - Treatment - Adhesive Combinations for Glulam Purpose. International Journal of Composite Materials (Online), v. 4, p. 41-47, 2014.

[6] Christoforo, A. L.; Rocco, F. A. L.; Chahud, E.; Branco, L. A. M. N.; Battistelle, R. A. G.; Valarelli, I. D. Influence of Storage Period of Pieces in Stiffness of Pinus elliottii Glulam Beams. Advanced Materials Research (Online), v. 1025-1026, p. 64-67, 2014.

[7] Canadian Standards Association, CAN/CSA 077. Qualification Code for Manufactures of Structural Glued Laminated Timber, 2006, 16p.

[8] Almeida, D. H.; Cavalheiro, R. S.; Macedo, L. B.; Calil Neto, C.; Christoforo, A. L.; Calil Junior, C.; Rocco, F. A. L. Evaluation of Quality in the Adhesion of Glued Laminated Timber (Glulam) of Paricá and Lyptus Wood Species. International Journal of Materials Engineering, v. 4, p. 114-118, 2014.

[9] Segundinho, P. G. A.; Calil Neto, C.; Dias, A. A.; Calil Jr., C.; Christoforo, A. L. Evaluation of Brazilian reforestation species in glulam beams before and after preservative chemical treatments. International Journal of Materials Engineering, v. 4, p. 192-195, 2014.

[10] Zangiácomo, A. L.; Rocco Lahr, F. A. Brazilian alternative tropical wood in glulam production. In: IX World Conference on Timber Engineering, 2006, Portland, USA. Proceedings of the IX WCTE. Corvallis, USA: Oregon State University Conference Services, 2006. v. CDROM.

[11] Glued Laminated Timber Association - GLTA. Specifiers Guide, Inglaterra, 2006, 34p. Disponível em: <http://www.gl ulam.co.uk/pdfs/Specifiers Guide.pdf $>$. Acesso em: 16 maio 2013.

[12] Brazilian Association of Technical Standard - ABNT. NBR 7190. Timber structures design, Rio de Janeiro, 1997, 107 p.

[13] American Society of Testing and Materials - ASTM. D245. Standard practice for establishing structural grades and related allowable properties for visually graded Lumber, West Conshohocken, 2011, 16p. 